\title{
Predicting Short-term Market Returns and Volatility Using Index of Consumer Sentiment
}

\author{
Rama Krishna Yelamanchili ${ }^{1}$ \\ ${ }^{1}$ Associate Professor of Finance, Department of Accounting \& Finance, ICFAI Business School, ICFAI University, \\ Hyderabad, Telangana, India \\ Correspondence: Rama Krishna Yelamanchili, Associate Professor of Finance, Department of Accounting \& Finance, \\ ICFAI Business School, ICFAI University, Hyderabad, Telangana, India. E-mail: yrk@ibsindia.org, \\ yramphd@yahoo.com
}

Received: May 15, 2019

Accepted: June 9, 2019

Online Published: July 2, 2019

doi:10.5430/afr.v8n3p72

URL: https://doi.org/10.5430/afr.v8n3p72

\begin{abstract}
This study examines the short-term predictive ability of Index of Consumer Sentiment (ICS) about Indian stock market returns. Monthly values of ICS, six broad market indices, and nine sectorial indices are collected. The paper finds significant contemporaneous co-movement between S\&PBSE500 and other indices. There is no contemporaneous co-movement between ICS and 15 indices. With one lag, ICS Granger cause two sectorial indices and four broad market indices. The one period ahead predictive regression model finds that sentiment has some predictive power of small cap, mid cap and BSE500 index returns. The effect is negative and statistically significant. The predictive regression result indicates that following month of high consumer sentiment, small cap, midcap, and BSE500 index returns decline and vice-versa. However, there is no association between ICS and large cap index and sentiment has no predictive ability of large cap index. The result of variance model indicate that ARCH term and GARCH term are insignificant indicating that the market has no long memory and new shocks will not persist to many future periods. The paper finds no volatility clustering and volatility persistence except in case of small cap index. This paper finds presence of noise trade and investors over-reaction in small cap stocks. EGARCH result supports for the presence of leverage effect, and confirms negative impact of consumer sentiment on small cap stocks.
\end{abstract}

Keywords: efficient market hypothesis, prospect theory, investor sentiment, herd behavior, collectivism

\section{Introduction}

Traditional finance theory depends on assumptions that investors act rationally, markets are fully efficient and prices hold random walk behavior. According to Efficient Market Hypothesis (EMH), stock prices reflect all available information and it is not possible to earn abnormal gains. Abnormal gains may only possible from taking high risk. The theory proposes that investors are rational and no individual investor has power to affect the stock prices. Moreover, EMH assumes that transaction costs are minimal (Fama, 1970). Empirically there is indication of continued price abnormalities in the stock markets. Previous literature attempt to relate these price anomalies to the presence of investors' under-reaction and over-reaction (Barberis, Shleifer, \& Vishny, 1998; Daniel, Hirshleifer, \& Subrahmanyam, 1998). Few researchers also attempt to link price anomalies to noise trade theory and find that some investors do indeed trade on noise instead of fundamentals (Black, 1986; De Long, Shleifer, Summers, \& Waldmann, 1990).

In contrast to conventional finance theory, behavioral finance approach believes that investors are not rational, they should be considered as normal. Investors take decisions not only based on risk, return and utility maximization; they take decisions based on satisfaction that is shaped by cognitive and emotional biases (Pompian, 2012). According to behavioral finance, stock markets are not fully efficient.

If investors take decisions depending on their psychological motivations and those decisions affect security markets, then there should be close interface between investor behavior and stock market movement. That is the reason why central banks, regulators, and governments pay special attention to accomplish expectations of investors. Investor sentiment is an important indicator that shows expectations of investors. Because investor sentiment may differently affect different stocks, relation between investor sentiments and different stock indices need to be analyzed. 
According to Baker and Wurgler (2007), consumer sentiment represents a belief about future cash flows and risk, which is not justified by economic and financial information. Brown and Cliff (2004) considered that "sentiment represents the expectations of market participants relative to a norm: a bullish (bearish) outlook means investors expect returns to be above (below) average, whatever "average" may be". Brown and Cliff (2005) highlight that investor sentiment is driven by a persistent uninformed demand shocks.

Shleifer (2000) defines investor sentiment as heuristic behavior in which investment decisions depends on belief or rules of thumb rather than Bayesian rationality. Some researchers refer to investor sentiment as the inclination to trade on noise rather than information (Baker, Wurgler, \& Yuan, 2012). The proposition of noise trading by Black (1986) introduced a number of behavioral factors that are subsequently developed by other researchers (Campbell \& Kyle, 1993; De Long, Shleifer, Summers, \& Waldmann 1991).

According to Shleifer and Summers (1990), noise traders tend to be on average more aggressive than arbitrageurs are either because they are overly optimistic or overconfident. Thus, they take on a higher level of risk. If the risk-taking is rewarded by the market, noise traders can earn high returns, thereby acquiring even more confidence, continuing to trade thusly. When noise traders earn high returns, other investors tend to imitate them, ignoring the fact that the gains obtained involved a higher level of risk and have essentially been the result of luck. This imitation brings to the market more application of money in strategies based on noise.

Other researchers refer noise trade to investors' excessive pessimism (bearish) or optimism (bullish) towards the stock market's current and future price (Brown \& Cliff, 2004; Shefrin, 2008). Olsen (1998) suggested that investors who make decisions under time pressure tend to dip in inevitable emotions that tend into more volatile stock price movements. The asymmetric treatment of gains versus losses is a central concept in the "prospect theory" of asset pricing (Kahneman \& Tversky 1979). Kahneman and Tversky (1979) developed the Prospect Theory, which claims that people are loss averse, i.e. losses are felt much more intensely than gains. Second, people judge good and bad things in relative to their current situation. Third, as diminishing marginal utility for gains, each successive unit of loss hurts less painfully than the previous one.

Measuring the effect of consumer sentiment on stock market returns has been an encouraging research interest, perhaps partly due to historical events and empirical puzzles that seem to defy the traditional finance theory of market efficiency. While a number of studies find that consumer sentiment predicts stock market returns in developed countries, there is limited research in emerging economies, especially in India.

According to Chui, Titman, and Wei (2010) a collectivist culture is a driver of investors' tendency to herding, which in the capital market can lead to the possibility of noise traders' errors being correlated. Schmeling (2009) examined the extent to which sentiment influenced market returns in countries with different cultures. He find that countries that had high levels of collectivism showed a strong effect of sentiment on stock returns, concluding that countries with a cultural tendency for herding were subject to a strong sentiment-return relationship. According to Hofstede (2001), India has high level of collectivism. This idea is another motivating factor for this paper.

Sentiment measures can be divided into two groups: explicit measures, when the sentiment indicator is derived directly from investor surveys and implicit measures, when the indicator is obtained from indirect proxies. This paper considers explicit consumer sentiment measure i.e., the index of consumer sentiment (ICS) jointly produced by BSE-CMIE-University of Michigan. There are abundance of empirical studies that have noted significant relationships between ICS and stock market returns in developed markets (Chen, 2011; Fisher \& Statman, 2003; Ho \& Hung, 2012; Hsu, Lin, \& Wu, 2011; Jansen \& Nahuis, 2003). ICS has been used in research works of Bergman and Roychowdhury (2008), Lemmon and Portniaguina (2006), and Schmeling (2009). Findings of these studies thus provide a strong base for the adoption of the ICS as a proxy of investor sentiment in the context of this study.

This study has theoretical and empirical motivations. Firstly, most of existing studies focus on individualist countries and major capital markets, mainly the U.S. market. Secondly, many of the studies until now investigate the impact of sentiment on certain categories of assets or portfolios. However, there are only small numbers of studies whose analysis focused on the aggregate market or on specific sectors. As discussed above investors behavior may not be the same in individualistic and collectivistic societies. There is a need to understand the association between investor sentiment and stock price movements in the context of collectivistic countries. Furthermore, there is a need to assess the intensity of investor sentiment on different sectors along with broad market movement. This paper tries to address these issues. This paper investigates whether investor sentiment predicts future aggregate stock market returns in India. 


\section{Literature Review}

Factors influencing stock returns and prediction of stock returns have always been an interesting subject of modern security analysis. It is posited that there may be some relation between investors' expectations and stock market movements. There have been several studies, examining the relation between consumer confidence and market movements. These studies principally focused on consumer confidence index and stock market returns.

Shiller (2005) explains a simple and intuitive feedback model of stock price movements. If prices start to rise, the success of some investors attracts public attention that fuels enthusiasm for the market. New (and often less sophisticated) investors enter the market and help bid up prices. Upward price motion begets expectations of further upward motion to the point where "irrational exuberance" may cause prices to exceed levels that can be justified by fundamentals. However, if prices begin to drop, pessimism can take hold, causing some investors to exit the market. Downward price motion begets expectations of further downward motion, and so on, until a bottom is eventually reached. In his recent work, Shiller (2017) argues that investors' optimistic or pessimistic beliefs about the stock market are similar to fads that can spread throughout the popular culture like an infectious disease.

Otoo (1999) find strong positive relationship between Michigan University's consumer confidence index and stock prices and reports that stock returns influence consumer sentiment. An increase in stock prices boosts consumer sentiment. Jensen and Nahuis (2003) find positive correlation between consumer confidence and stock market movements in short-run and reports that stock returns Granger-cause consumer confidence at very short period, but not vice versa. Baker and Verma (2007) indicate that investor sentiment has a positive effect on stock returns but has a negative effect on market volatility for both individual and institutional investors. Baker and Wurgler (2007) find that younger, smaller, more volatile, unprofitable, and non-dividend paying stocks are most sensitive to investor sentiment. Bremmer (2008) reports that there is no long-run relationship between University of Michigan's measure of consumer confidence and different stock indices, and in short run, stock prices Granger-cause consumer confidence, but not vice versa. Verma and Soydemir (2009) find that individual and institutional investor sentiments are driven by both rational and irrational factors. Lux (2011) finds a feedback relationship between the stock returns and sentiment. Zhu (2012) shows a strong correlation between sentiment index and Shanghai stock market index. Changsheng and Yongfeng (2012) show that investor sentiment has incremental power to explain return co-movement indicating that when investors are bullish the stock return is high and it is low when the investors are bearish. $\mathrm{Li}$ (2014) shows that the sentiment index has a good predictive power of Chinese stock market return.

In contrast to above mentioned research findings, Schmeling (2009) find that sentiment negatively forecasts aggregate stock market returns on average. Similarly, Shen, Yu, and Zhao (2017) find that higher levels of investor sentiment tend to predict lower excess returns when comparing high-risk stock portfolios to low-risk portfolios. Lemmon and Portniaguina (2006) find that higher levels of sentiment forecast lower future returns on value stocks but not growth stocks. They posit that investors seemed to overestimate small stocks relative to large stocks during periods of high confidence and vice versa. Fisher and Statman (2003) find that there is a negative and statistically significant relationship between the sentiment level of individual investors and returns in the following month on high capitalization stocks. Brown and Cliff (2005) find that in the stock market there is a statistically significant negative coefficient estimate for $\beta$. Therefore, periods of higher investor optimism tend to be followed by significantly lower returns for the aggregate market (Baker \& Wurgler, 2006; Lemmon \& Portniaguina, 2006).

With regard to time horizon, Fischer and Statman (2003) find that measures of sentiment alone have little predictive power over short horizons. However, Brown and Cliff (2005) report that the market is overvalued during periods of optimism and find that higher levels of sentiment forecast negative returns over longer horizons.

Chui, Titman, and Wei (2008) try to explain the relationship between consumer sentiment and stock returns from culture perspective. Chui, Titman, and Wei (2008) propose that cultural differences might play a role for the relative strength of behavioral biases between countries. They argue that stock markets in collectivistic countries are more heavily influenced by investor sentiment whereas stock markets in individualistic countries should be less affected by behavioral biases.

Some researchers modeled volatility in the context of consumer sentiment and market momentum. Olsen (1998) advise that investors who make decisions under time pressure incline to engage in unavoidable emotions that swell into more volatile stock price movements. Wang, Keswani, and Taylor (2006) investigate the causal relationship between sentiment, returns and volatility, and find that investor sentiments caused by market returns and volatility rather than vice versa. Chuang, Ouyang, and Lo (2010) conclude that the volatility that generated from investor sentiment gives rise to idiosyncratic risk rather than systematic risk. Perez-Liston, and Huerta (2012) shows that the bullish shift in investor sentiment has negative effect on conditional volatility. 
To sum up the literature, we can conclude that first, different indicators are used as proxy to represent consumer and/or investor sentiments. Second, the effect of sentiment on stock prices is limited, or only for certain type of stocks and for a short period of time the causality exists. Third, generally, instead of from sentiment to stock prices, the direction of causality is from stock returns towards sentiments.

\section{Objective}

While a number of studies find that consumer sentiment predicts stock market returns in developed countries, there is limited research in emerging economies, especially in India. Moreover, no much research is conducted in the context of collectivist country, considering multiple indices, short period horizon, and modeling volatility with sentiment indicator. This study investigates the contemporaneous co-movements between ICS and market indices, causality between ICS and market indices, and examines whether investor sentiment predicts one period ahead (time horizon) aggregate stock market and sectorial indices returns (multiple indices) in India (collectivist country) by modeling volatility with ICS (sentiment indication). This paper tests the hypotheses that there will be significant contemporaneous co-movements between broad market index and sectorial indices. Similarly, there will be contemporaneous co-movements between ICS and stock indices. Next, there will be causality from ICS to market indices. Finally, this paper tests the hypothesis of short-term predictive ability of ICS of different stock indices. By validating these hypotheses this paper will contribute empirical evidence to the existing theories of market behavior.

\section{Data and Empirical Results}

This paper focuses on the Indian stock market and investigates the link between consumer sentiment and stock market returns using monthly data from 2016M01 to 2019M01. The Bombay Stock Exchange (BSE), The Centre for Monitoring Indian Economy (CMIE) and University of Michigan are jointly producing Index of Consumer Sentiment (ICS) in India since 2016M01. In this study, I used the ICS as proxy for consumer sentiment and gathered data from its inception in India. Many studies in developed countries use the ICS as a proxy for investor sentiment and show that it can predict stock returns (Brown \& Cliff, 2005; Fisher \& Statman, 2003; Lee, Jiang, \& Indro, 2002; Lemmon \& Portniaguina, 2006; Ho \& Hung, 2009). For the same period, indices values are collected for 15 market indices of which six are broad market indices and nine are sectorial indices from the BSE. As the data is limited to three-year time-period and number of observations is small, all necessary steps are taken to validate the data. Data availability is one of the limitations of this study. This happened because of producing ICS in India started in year 2016. This limitation is an opportunity to study the ICS in its nascent stage in collectivistic country like India. This also gave me another opportunity i.e. worldwide ICS produced by University of Michigan is considered as one of the meticulous surveys to measure consumer sentiment, this study examines how far ICS measures Indian investors' sentiment and does it have any predictive ability of Indian stock markets.

\subsection{Unit Root Tests}

To avoid regression with spurious results, each series is tested for a unit root. Before that, I calculated $\log$ returns of all variables using equation 1 . For all series considered in this study, unit root tests are conducted to investigate whether these series are stationary or not. Results of the Phillips-Perron (PP) test, Augmented Dickey Fuller (ADF) test, along with Auto Correlation (AC) and Partial Auto Correlation (PAC) are reported in table 1. The results of PP and $\mathrm{ADF}$ tests indicate that all the variables are stationary at $1 \%$ level of significance, and the null hypothesis of a zero root is rejected.

$$
\mathrm{r}_{\mathrm{t}}=\ln \left(\mathrm{p}_{\mathrm{t}} / \mathrm{p}_{\mathrm{t}-1}\right) * 100
$$

where, $r_{t}$ represents return as percentage, $p_{t}$ price or index value at time $t, p_{t-1}$ price or index value at time $e_{t-1}$. 
Table 1. Unit root test results

\begin{tabular}{|c|c|c|c|c|c|c|}
\hline Index & $\mathrm{ADF}$ & PP & $\mathrm{AC}$ & PAC & Q-Stat & Prob \\
\hline \multicolumn{7}{|c|}{ Sector / Industry Indices } \\
\hline CDGS & -2.72 & -5.13 & 0.12 & 0.12 & 0.59 & 0.44 \\
\hline Energy & -7.28 & -8.30 & -0.19 & -0.19 & 1.40 & 0.24 \\
\hline Finance & -4.83 & -6.46 & -0.05 & -0.05 & 0.10 & 0.75 \\
\hline FMCG & -4.94 & -6.39 & -0.08 & -0.08 & 0.23 & 0.64 \\
\hline HealthCare & -7.64 & -8.92 & -0.25 & -0.25 & 2.48 & 0.12 \\
\hline Industrials & -2.72 & -6.75 & -0.13 & -0.13 & 0.66 & 0.42 \\
\hline InfoTech & -7.36 & -7.24 & -0.21 & -0.21 & 1.72 & 0.19 \\
\hline Materials & -6.10 & -6.19 & -0.06 & -0.06 & 0.13 & 0.71 \\
\hline Telecom & -6.23 & -6.22 & -0.08 & -0.08 & 0.24 & 0.62 \\
\hline \multicolumn{7}{|c|}{ Market Cap / Broad } \\
\hline BSESensex & -5.34 & -7.39 & -0.18 & -0.18 & 1.26 & 0.26 \\
\hline S\&PBSE100 & -5.35 & -7.01 & -0.13 & -0.13 & 0.69 & 0.41 \\
\hline S\&PBSE200 & -5.40 & -6.85 & -0.11 & -0.11 & 0.49 & 0.49 \\
\hline S\&PBSE500 & -5.30 & -6.73 & -0.09 & -0.09 & 0.34 & 0.56 \\
\hline MidCap & -6.05 & -6.05 & -0.03 & -0.03 & 0.02 & 0.88 \\
\hline SmallCap & -6.41 & -6.39 & -0.04 & -0.04 & 0.08 & 0.78 \\
\hline \multicolumn{7}{|c|}{ Sentiment } \\
\hline ICS & -5.92 & -6.67 & -0.03 & -0.03 & 0.04 & 0.85 \\
\hline \multicolumn{7}{|c|}{ Test critical values: } \\
\hline & $1 \%$ level & $5 \%$ level & $10 \%$ level & & & \\
\hline & -3.63 & -2.95 & -2.61 & & & \\
\hline
\end{tabular}

\subsection{Contemporaneous Co-Movement Tests}

I then conducted contemporaneous co-movement analysis between each index and S\&PBSE500 (Market Indicator) and ICS (Sentiment Indicator). I find significant positive contemporaneous co-movement between market indicator and each index. The $\mathrm{R}^{2}$ values ranged between 0.20 and $0.99(p=0.00)$. However, $\mathrm{I}$ do not find any contemporaneous co-movement between index of consumer sentiment indicator and indices. The results are reported in table 2. These results are in contrast to the results of Brown and Cliff (2004) who find that investor sentiment is significantly correlated with the contemporaneous returns and Huang et al. (2014) who find that sentiment has positively related to current periods stock returns, whereas negatively related with lagged stock returns. 
Table 2. Contemporaneous co-movements (BSE500, ICS)

\begin{tabular}{|c|c|c|c|c|c|c|}
\hline \multicolumn{7}{|c|}{ Contemporaneous Co-movement between S\&P BSE 500 and Indices } \\
\hline Index & Coefficient & Std. Error & t-Statistic & Prob. & R-squared & F-statistic \\
\hline CDGS & 1.09 & 0.09 & 12.11 & 0.00 & 0.81 & 146.75 \\
\hline Energy & 0.96 & 0.17 & 5.78 & 0.00 & 0.50 & 33.40 \\
\hline Finance & 1.18 & 0.08 & 14.90 & 0.00 & 0.87 & 222.15 \\
\hline FMCG & 0.83 & 0.10 & 8.48 & 0.00 & 0.68 & 71.95 \\
\hline Healthcare & 0.60 & 0.17 & 3.45 & 0.00 & 0.26 & 11.92 \\
\hline Industrials & 1.33 & 0.09 & 14.38 & 0.00 & 0.86 & 206.66 \\
\hline InfoTech & 0.57 & 0.19 & 2.95 & 0.01 & 0.20 & 8.68 \\
\hline Materials & 1.28 & 0.12 & 10.53 & 0.00 & 0.77 & 110.78 \\
\hline Telecom & 0.82 & 0.21 & 3.88 & 0.00 & 0.31 & 15.09 \\
\hline S\&PBSE_Sensex & 0.89 & 0.05 & 17.36 & 0.00 & 0.90 & 301.52 \\
\hline S\&PBSE_100 & 0.94 & 0.02 & 38.90 & 0.00 & 0.98 & 1513.16 \\
\hline S\&PBSE_200 & 0.97 & 0.01 & 81.03 & 0.00 & 0.99 & 6566.37 \\
\hline S\&PMid_Cap & 1.14 & 0.08 & 14.22 & 0.00 & 0.86 & 202.16 \\
\hline S\&PSmall_Cap & 1.31 & 0.11 & 11.60 & 0.00 & 0.80 & 134.59 \\
\hline \multicolumn{7}{|c|}{ Contemporaneous Co-movement between ICS and Indices } \\
\hline CDGS & -0.12 & 0.39 & -0.31 & 0.76 & 0.00 & 0.10 \\
\hline Energy & 0.55 & 0.43 & 1.29 & 0.21 & 0.05 & 1.67 \\
\hline Finance & 0.02 & 0.40 & 0.06 & 0.95 & 0.00 & 0.00 \\
\hline FMCG & -0.11 & 0.32 & -0.33 & 0.74 & 0.00 & 0.11 \\
\hline Healthcare & -0.11 & 0.37 & -0.30 & 0.77 & 0.00 & 0.09 \\
\hline Industrials & -0.16 & 0.46 & -0.34 & 0.74 & 0.00 & 0.11 \\
\hline InfoTech & 0.36 & 0.40 & 0.92 & 0.36 & 0.02 & 0.84 \\
\hline Materials & -0.40 & 0.46 & -0.86 & 0.39 & 0.02 & 0.74 \\
\hline Telecom & -0.52 & 0.47 & -1.11 & 0.27 & 0.03 & 1.24 \\
\hline S\&PBSE_Sensex & 0.13 & 0.30 & 0.43 & 0.67 & 0.00 & 0.18 \\
\hline S\&PBSE_100 & 0.06 & 0.30 & 0.19 & 0.85 & 0.00 & 0.04 \\
\hline S\&PBSE_200 & 0.04 & 0.31 & 0.12 & 0.90 & 0.00 & 0.01 \\
\hline S\&PBSE_500 & 0.02 & 0.32 & 0.06 & 0.96 & 0.00 & 0.00 \\
\hline S\&PMid_Cap & -0.06 & 0.39 & -0.15 & 0.88 & 0.00 & 0.02 \\
\hline S\&PSmall_Cap & -0.16 & 0.47 & -0.33 & 0.74 & 0.00 & 0.11 \\
\hline
\end{tabular}

4.3 Granger Causality Tests

I then conducted granger causality tests with one lag. First, I tested granger causality between S\&PBSE500 and indices. I find that ICS granger caused S\&PBSE500 at 10\% significance level $(p=0.09)$. Excluding this granger causality, the null hypothesis that market indicator granger causes stock indices cannot be rejected. Next, I tested the granger causality between ICS and Indices. The ICS granger caused two sectorial indexes (Energy $(p=0.06)$, Finance $(p=0.04))$ and four broad market indexes (S\&PBSE200 $(p=0.10)$, S\&PBSE500 $(p=0.09)$, MidCap $(p=$ $0.07)$ and SmallCap $(p=0.06)$ ). For the remaining nine series, the null hypothesis that a consumer sentiment granger causes stock index cannot be rejected. This indicates that there is no causal relation from consumer sentiment towards market momentum and consumer sentiment neither can be used to predict future market returns and nor can be a leading indicator in case of these nine indices. The Granger causality test result is reported in table 3 . 
Table 3. Granger Causality (S\&PBSE500, ICS)

\begin{tabular}{|c|c|c|}
\hline \multicolumn{3}{|c|}{ Granger Causality between S\&P BSE 500 and Indices } \\
\hline Index & S\&P BSE 500 does not Granger Cause Index & Index does not Granger Cause S\&P BSE 500 \\
\hline CDGS & 0.01 & 0.00 \\
\hline Energy & 0.12 & 0.16 \\
\hline Finance & 0.43 & 0.28 \\
\hline FMCG & 0.75 & 0.66 \\
\hline Healthcare & 0.42 & 0.74 \\
\hline Industrials & 0.22 & 0.61 \\
\hline InfoTech & 0.85 & 0.06 \\
\hline Materials & 0.73 & 0.49 \\
\hline Telecom & 0.50 & 0.15 \\
\hline S\&P BSE Sensex & 0.27 & 0.36 \\
\hline S\&P BSE 100 & 0.35 & 0.41 \\
\hline S\&P BSE 200 & 0.47 & 0.49 \\
\hline ICS & 0.40 & 0.09 \\
\hline MidCap & 0.60 & 0.28 \\
\hline SmallCap & 0.92 & 0.53 \\
\hline \multicolumn{3}{|c|}{ Granger Causality between ICS and Indices } \\
\hline Index & ICS does not Granger Cause Index & Index does not Granger Cause ICS \\
\hline CDGS & 0.12 & 0.31 \\
\hline Energy & 0.06 & 0.63 \\
\hline Finance & 0.04 & 0.56 \\
\hline FMCG & 0.82 & 0.44 \\
\hline Healthcare & 0.24 & 0.41 \\
\hline Industrials & 0.16 & 0.33 \\
\hline InfoTech & 0.97 & 0.31 \\
\hline Materials & 0.25 & 0.38 \\
\hline Telecom & 0.11 & 0.22 \\
\hline S\&P BSE Sensex & 0.26 & 0.91 \\
\hline S\&P BSE 100 & 0.13 & 0.59 \\
\hline S\&P BSE 200 & 0.10 & 0.47 \\
\hline S\&P BSE 500 & 0.09 & 0.40 \\
\hline MidCap & 0.07 & 0.12 \\
\hline SmallCap & 0.06 & 0.12 \\
\hline
\end{tabular}

4.4 Predictive Regression

As granger causality tests result in causation from index of consumer sentiment to six indices, I proceeded to predict one period ahead (short horizon) market momentum for these six indexes. In this study, I focus on the relation between consumer sentiment and market momentum, which has not gained much attention in the literature. I examine if consumer sentiment is able to predict market momentum in short horizon i.e., following month. To observe whether consumer sentiment predicts future stock market returns and industry indices returns, I estimate the predictive regression equation of the form: 


$$
r_{t+1}=\beta_{0}+\beta . \text { Sent }_{t}+\epsilon_{t}
$$

where $r_{t+1}$ is the return of the aggregate stock market portfolio at time $t+1$ and sentiment is a proxy for (one lag) consumer sentiment (ICS).

The prediction regression results are reported in table 4. I do not perform long horizon predictability regression because the series are stationary and the empirical reliability of such results has been called into question by Boudoukh, Richardon, and Whitelaw (2008), and Bauer and Hamilton (2017). The short horizon regression results show that sentiment has some predictive power for market returns. The estimated coefficients are negative and statistically significant at $10 \%$ level. The $\mathrm{R}^{2} \mathrm{~s}$ of the regressions ranged between 0.08 and 0.12 , signifying that a small portion of returns can only be explained by index of consumer sentiment. My results are in line few with previous studies (Schmeling, 2009; Fisher and Statman, 2000) which report negative relationship between lagged consumer sentiment and stock market movements. In other words following month of high consumer sentiment, market returns decline. In this case, an increase of one point in the sentiment level is associated, on average, with a $0.7 \%$ decrease in market returns in the following month.

The estimation results of regressions of the nine sectorial indices show that consumer sentiment only has negative and statistically significant impact in case of Energy sector and Finance sector at the 5\% level $(p=0.04)$ for forecast horizon of one month. In these two sectors, the capacity for sentiment to anticipate future returns is 0.12 . These results indicate that these sectors may be more susceptible to the effects of consumer sentiment. Following month of high consumer sentiment returns in these sectors decline. In other sectors, consumer sentiment appears to have no predictive power on returns.

Table 4. Predictive regression (ICS vs. Indices)

\begin{tabular}{rlrrrrrr}
\hline \multicolumn{1}{c}{ 2016M02 2019M01 Index C ICS(-1) } \\
\hline S.No & Index & \multicolumn{1}{c}{ Coefficient } & \multicolumn{1}{c}{ Std. Error } & \multicolumn{1}{c}{ t-Statistic } & Prob. & \multicolumn{1}{c}{ R$^{\wedge}$} & \multicolumn{2}{c}{ F-statistic } \\
\hline 1 & Energy & -0.85 & 0.40 & -2.13 & 0.04 & 0.12 & 4.55 \\
2 & Finance & -0.77 & 0.36 & -2.15 & 0.04 & 0.12 & 4.62 \\
3 & S\&PBSE200 & -0.49 & 0.28 & -1.71 & 0.10 & 0.08 & 2.93 \\
4 & S\&PBSE500 & -0.52 & 0.29 & -1.79 & 0.08 & 0.09 & 3.20 \\
5 & MidCap & -0.71 & 0.37 & -1.94 & 0.06 & 0.10 & 3.75 \\
6 & SmallCap & -0.83 & 0.42 & -1.97 & 0.06 & 0.10 & 3.87 \\
\hline
\end{tabular}

4.5 Predictive Regression (Sub-Period)

Because over the entire period of investigation the effect of consumer sentiment on stock indices returns are negative and found significant at 10\% level, I examine three sub-periods (2016M02 - 2017M01, 2017M02 - 2018M01, and 2018M02 - 2019M01) in order to test its consistency on indices returns. Results of sub-period predicted regressions are reported in table 5. The general finding conveyed by these results are that, in the first sub-period consumer sentiment significant negatively affect stock market returns at 5\% level. By the third period, the coefficients are negative but very low and insignificant, indicating that consumer sentiment does not play any role over this period. Furthermore, the $\mathrm{R}^{2} \mathrm{~s}$ are zero indicating that variations in excess returns are not explained by consumers' sentiment. This paradox could be attributed to the extreme sternness of both the upswing and downswing phases of market cycle. During which excitement and fear seemingly was out one another, thus navigating the sentiment effect or perhaps, the number of stocks positively affected by bullish sentiment is roughly the same as those that are negatively affected by bearish sentiment and thus they cancel each other. 
Table 5. Sub-Period Predictive Regression

\begin{tabular}{|c|c|c|c|c|c|c|c|}
\hline \multicolumn{8}{|c|}{ 2016M02 2017M01 Index C ICS(-1) } \\
\hline S.No & Index & Coefficient & Std. Error & t-Statistic & Prob. & $\mathrm{R}^{\wedge} 2$ & F-statistic \\
\hline 1 & Energy & -0.70 & 0.83 & -0.85 & 0.42 & 0.07 & 0.72 \\
\hline 2 & Finance & -2.58 & 1.01 & -2.57 & 0.03 & 0.42 & 0.58 \\
\hline 3 & MidCap & -2.51 & 0.92 & -2.73 & 0.02 & 0.50 & 7.43 \\
\hline 4 & S\&PBSE200 & -1.93 & 0.76 & -2.54 & 0.03 & 0.42 & 6.43 \\
\hline 5 & S\&PBSE500 & -2.01 & 0.76 & -2.64 & 0.03 & 0.44 & 6.95 \\
\hline 6 & SmallCap & -2.74 & 0.92 & -2.99 & 0.02 & 0.50 & 8.91 \\
\hline \multicolumn{8}{|c|}{ 2017M02 2018M01 Index C ICS(-1) } \\
\hline S.No & Index & Coefficient & Std. Error & t-Statistic & Prob. & $\mathrm{R}^{\wedge} 2$ & F-statistic \\
\hline 1 & Energy & -1.03 & 0.43 & -2.40 & 0.04 & 0.37 & 5.78 \\
\hline 2 & Finance & -0.43 & 0.27 & -1.63 & 0.13 & 0.21 & 2.64 \\
\hline 3 & MidCap & -0.43 & 0.27 & -1.59 & 0.14 & 0.21 & 2.54 \\
\hline 4 & S\&PBSE200 & -0.27 & 0.22 & -1.20 & 0.26 & 0.13 & 1.44 \\
\hline 5 & S\&PBSE500 & -0.29 & 0.22 & -1.32 & 0.22 & 0.15 & 1.73 \\
\hline 6 & SmallCap & -0.50 & 0.31 & -1.63 & 0.14 & 0.21 & 2.64 \\
\hline \multicolumn{8}{|c|}{ 2018M02 2019M01 Index C ICS(-1) } \\
\hline S.No & Index & Coefficient & Std. Error & t-Statistic & Prob. & $\mathrm{R}^{\wedge} 2$ & F-statistic \\
\hline 1 & Energy & -0.09 & 1.24 & -0.07 & 0.94 & 0.00 & 0.00 \\
\hline 2 & Finance & -0.64 & 1.00 & -0.64 & 0.54 & 0.03 & 0.41 \\
\hline 3 & MidCap & -0.26 & 1.02 & -0.25 & 0.81 & 0.00 & 0.06 \\
\hline 4 & S\&PBSE200 & -0.17 & 0.80 & -0.21 & 0.83 & 0.00 & 0.04 \\
\hline 5 & S\&PBSE500 & -0.18 & 0.81 & -0.23 & 0.83 & 0.00 & 0.05 \\
\hline 6 & SmallCap & -0.28 & 1.19 & -0.24 & 0.82 & 0.00 & 0.05 \\
\hline
\end{tabular}

4.6 Volatility Modeling

To model series volatility clustering, long memory, and volatility leverage I used GARCH $(1,1)$, and EGARCH $(1,1)$ models. While measuring volatility I used both mean model and variance model. Results indicate that ARCH term and GARCH term is insignificant, which mean that the market has no long memory and new shocks or surprises will not persist too many future periods. When I run mean model and variance model together, I find significant negative effect of consumer sentiment present only on Smallcap Index at 1\% level. For the remaining four indices the $p>0.05$, which mean the models are insignificant at 5\% level. Result indicates presence of noise trade and investors over reaction in small cap stocks. EGARCH $(1,1)$ result supports for the presence of leverage effect, and confirms that there is a negative impact of consumer sentiment on small cap stocks. It seems investors overestimate small cap stocks relative to large stocks during periods of high confidence and vice versa.

Table 6. Expected Return \& Volatility Models GARCH $(1,1)$

\begin{tabular}{lcrrrr}
\hline \multicolumn{5}{c}{ Energy Index } \\
\hline \multicolumn{5}{c}{ Mean $=\mathrm{C}(1)+\mathrm{C}(2) * \mathrm{ICS}(-1)+\mathrm{GARCH}=\mathrm{C}(3)+\mathrm{C}(4) * \mathrm{RESID}(-1)^{\wedge} 2+\mathrm{C}(5) * \mathrm{GARCH}(-1)$} \\
\hline \multicolumn{5}{c}{ Mean Equation } \\
\hline Variable & Coefficient & Std. Error & z-Statistic & Prob. \\
\hline $\mathrm{C}$ & & 2.32 & 0.97 & 2.40 & 0.02 \\
$\mathrm{ICS}(-1)$ & & -0.99 & 0.49 & -2.04 & 0.04 \\
& Variance Equation & & & & \\
\hline
\end{tabular}




\begin{tabular}{|c|c|c|c|c|}
\hline $\mathrm{C}$ & 18.18 & 23.92 & 0.76 & 0.45 \\
\hline $\operatorname{RESID}(-1)^{\wedge} 2$ & -0.13 & 0.21 & -0.61 & 0.54 \\
\hline GARCH(-1) & 0.46 & 0.91 & 0.51 & 0.61 \\
\hline $\mathrm{R}^{\wedge} 2$ & 0.11 & \multicolumn{2}{|c|}{ SE Regress } & 5.36 \\
\hline
\end{tabular}

Finance Index

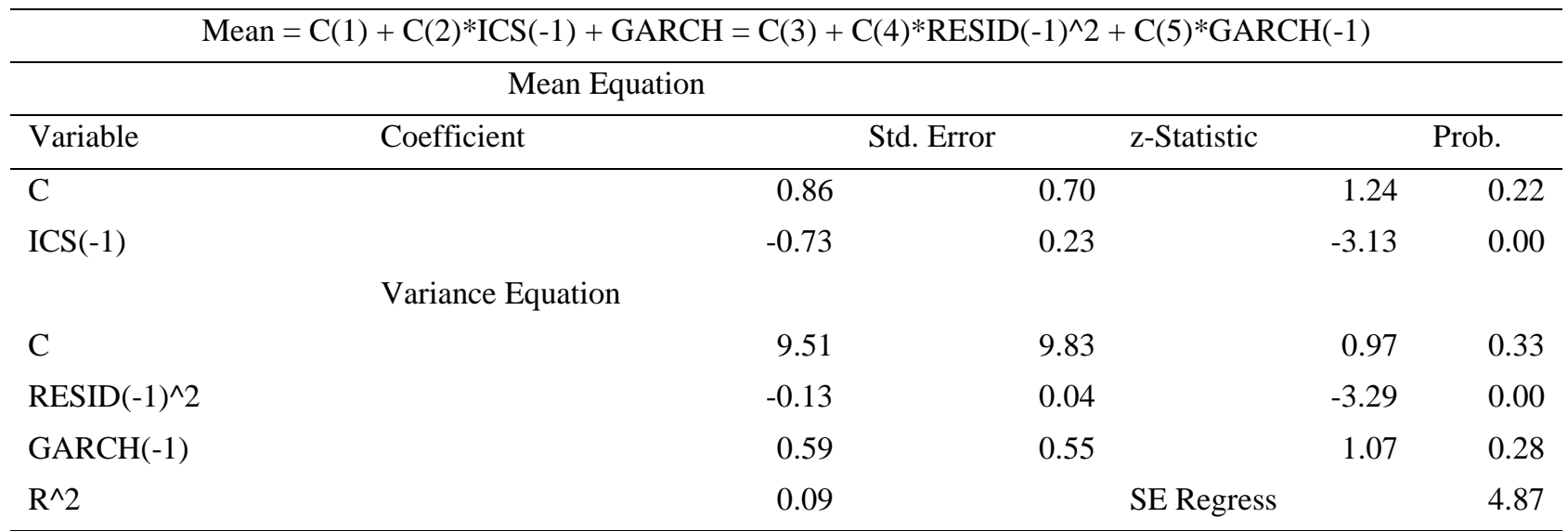

MidCap Index

\begin{tabular}{|c|c|c|c|c|c|c|}
\hline \multicolumn{7}{|c|}{$\begin{array}{r}\text { Mean }=\mathrm{C}(1)+\mathrm{C}(2) * \mathrm{ICS}(-1)+\mathrm{GARCH} \\
\text { Mean Equation }\end{array}$} \\
\hline \multirow{2}{*}{$\begin{array}{l}\text { Variable } \\
\mathrm{C}\end{array}$} & \multirow[t]{2}{*}{ Coefficient } & \multicolumn{2}{|r|}{ Std. Error } & \multirow[t]{2}{*}{ z-Statistic } & \multicolumn{2}{|c|}{ Prob. } \\
\hline & & 0.06 & 0.86 & & 0.07 & 0.94 \\
\hline $\operatorname{ICS}(-1)$ & & -0.67 & 0.39 & & -1.70 & 0.09 \\
\hline & Variance Ec & & & & & \\
\hline $\mathrm{C}$ & & 10.43 & 17.65 & & 0.59 & 0.55 \\
\hline $\operatorname{RESID}(-1)^{\wedge} 2$ & & -0.16 & 0.11 & & -1.38 & 0.17 \\
\hline GARCH(-1) & & 0.65 & 0.81 & & 0.80 & 0.43 \\
\hline $\mathrm{R}^{\wedge} 2$ & & 0.05 & & SE Regress & & 5.00 \\
\hline
\end{tabular}

SmallCap Index

\begin{tabular}{|c|c|c|c|c|c|c|}
\hline \multicolumn{7}{|c|}{ Mean $=\mathrm{C}(1)+\mathrm{C}(2) * \mathrm{ICS}(-1)+\mathrm{GARCH}=\mathrm{C}(3)+\mathrm{C}(4) * \mathrm{RESID}(-1)^{\wedge} 2+\mathrm{C}(5) * \mathrm{GARCH}(-1)$} \\
\hline \multicolumn{7}{|c|}{ Mean Equation } \\
\hline Variable & Coefficient & & Std. Error & z-Statistic & & \\
\hline $\mathrm{C}$ & & -0.24 & 0.99 & & -0.24 & 0.81 \\
\hline ICS(-1) & & -0.84 & 0.08 & & -10.46 & 0.00 \\
\hline & Variance Eq & & & & & \\
\hline $\mathrm{C}$ & & 14.11 & 17.03 & & 0.83 & 0.41 \\
\hline $\operatorname{RESID}(-1)^{\wedge} 2$ & & -0.13 & 0.15 & & -0.85 & 0.39 \\
\hline GARCH(-1) & & 0.60 & 0.67 & & 0.90 & 0.37 \\
\hline $\mathrm{R}^{\wedge} 2$ & & 0.05 & & SE Regress & & 5.77 \\
\hline
\end{tabular}




\begin{tabular}{|c|c|c|c|c|c|c|}
\hline \multicolumn{7}{|c|}{ S\&P BSE 200 Index } \\
\hline \multicolumn{7}{|c|}{ Mean $=\mathrm{C}(1)+\mathrm{C}(2) * \mathrm{ICS}(-1)+\mathrm{GARCH}=\mathrm{C}(3)+\mathrm{C}(4) * \mathrm{RESID}(-1)^{\wedge} 2+\mathrm{C}(5) * \mathrm{GARCH}(-1)$} \\
\hline \multicolumn{7}{|c|}{ Mean Equation } \\
\hline Variable & Coefficient & & Std. Error & z-Statistic & & \\
\hline $\mathrm{C}$ & & 1.19 & 0.72 & & 1.65 & 0.10 \\
\hline ICS(-1) & & -0.47 & 0.30 & & -1.55 & 0.12 \\
\hline \multicolumn{7}{|c|}{ Variance Equation } \\
\hline $\mathrm{C}$ & & 6.95 & 15.88 & & 0.44 & 0.66 \\
\hline $\operatorname{RESID}(-1)^{\wedge} 2$ & & 0.06 & 0.29 & & 0.19 & 0.85 \\
\hline GARCH(-1) & & 0.39 & 1.30 & & 0.30 & 0.77 \\
\hline $\mathrm{R}^{\wedge} 2$ & & 0.08 & & SE Regress & & 3.77 \\
\hline
\end{tabular}

\begin{tabular}{|c|c|c|c|c|c|c|}
\hline \multicolumn{7}{|c|}{ S\&P BSE 500 Index } \\
\hline \multicolumn{7}{|c|}{ Mean $=\mathrm{C}(1)+\mathrm{C}(2) * \mathrm{ICS}(-1)+\mathrm{GARCH}=\mathrm{C}(3)+\mathrm{C}(4) * \mathrm{RESID}(-1)^{\wedge} 2+\mathrm{C}(5) * \mathrm{GARCH}(-1)$} \\
\hline \multicolumn{7}{|c|}{ Mean Equation } \\
\hline Variable & Coefficient & & Std. Error & z-Statistic & & b. \\
\hline $\mathrm{C}$ & & 1.14 & 0.74 & & 1.54 & 0.12 \\
\hline ICS(-1) & & -0.48 & 0.31 & & -1.56 & 0.12 \\
\hline \multicolumn{7}{|c|}{ Variance Equation } \\
\hline $\mathrm{C}$ & & 6.79 & 18.28 & & 0.37 & 0.71 \\
\hline $\operatorname{RESID}(-1)^{\wedge} 2$ & & 0.02 & 0.27 & & 0.06 & 0.95 \\
\hline GARCH(-1) & & 0.47 & 1.42 & & 0.33 & 0.74 \\
\hline $\mathrm{R}^{\wedge} 2$ & & 0.09 & & SE Regress & & 3.86 \\
\hline
\end{tabular}

\section{Findings}

The study finds significant contemporaneous co-movement between broad market indicator (S\&PBSE500) and other indices considered in this study. At the same time, the paper does not find any contemporaneous co-movement between sentiment indicator (ICS) and indices. Next, the paper find that ICS granger causes six of 15 indexes, these causalities are negative and statistically significant. Among the six indices sectorial indices (Energy, and Finance) has significant coefficient of determination values confirming the negative causality. Further, the sub-period predictive analysis results reveal that the negative causality and strength of association are not consistent over the three sub-periods. Findings of the volatility analysis disclose no long memory, volatility persistence, and volatility clustering in all indices except small cap index. In case of small cap index the study, find volatility persistence and clustering. This finding is supported and confirmed through EGARCH analysis and indicates that there is presence of noise trade, investor optimism, pessimism, and over reaction in small cap stocks. Finally, the study also observed leverage effect in small cap index. Findings of this study are mixed. Primarily it supports the argument of Fisher and Statman (2003) that consumer sentiment alone have little predictive power and to some extent this paper reports similar results reported by Schmeling (2009) that sentiment negatively forecasts aggregate stock market returns. Importantly, the results of this study contradict the argument of investor sentiment positively affect stock markets as reported by Changsheng and Yongfeng (2012), Lux (2011), and Zhu (2012).

\section{Discussion}

Prima facie, there is no contemporaneous or causal relation between index of consumer sentiment (ICS) and broad market indices. This indicates that ICS has no predictive power of Indian stock markets, and cannot be considered as proxy for investor sentiment. To some extent, this paper finds empirical evidence for the argument that consumer sentiment negatively affect small cap index. The question that springs is why small cap stocks are negatively related 
to consumer sentiment. This may be because small cap stocks are excessively held by individual investors, who are more prone to the influence of sentiment. It also appears that propensity of individual investors to trade more on noise than on information. Volatility leverage in small cap index can be attributed to prospect theory. According to this theory, investors are loss averse and aggressively over react to bad news than to good news. Prospect theory argues that bad news has greater effect on volatility than good news of the same magnitude. This paper finds no contemporaneous co-movement between ICS and market indices. ICS sample comprises of household spread across India, however, how many of these household really invest in stocks is a question. In developed countries, individual investors invest in stocks judiciously, but in a developing country like India, investment in stocks by individual investors or households from rural and urban areas is limited. This raises a question for study further.

\section{Conclusion}

Based on the results of the study I conclude that ICS has no predictive power of short-horizon market movements. Indian stock market has no long memory and volatility clustering, which makes the prediction difficult. Investors need to be vigilant in trading smallcap stocks. In smallcap stocks, there is extreme trading during positive sentiment time. This indicates that more and more small investors without any fundamental knowledge or information about stocks, simply invest on noise. Initial returns may be high, but after some aggressive trading investors realize that stock prices are too high and will start selling to book profits. This creates panic among small investors and they rush to get rid of the small stocks. Resulting to leverage effect. Bad news spread faster and stock prices plunge hasty. Results of this paper lead to further research in the context of small cap stocks. This paper finds that consumer sentiment has negative short horizon predictive power of ICS of small cap index, but small cap index is different from small size stocks. Future research should be conducted on understanding the impact of ICS on small-size stocks.

\section{References}

Baker, M.P., Wurgler, J. \& Yuan, Y. (2012). Global, local, and contagious investor sentiment. Journal of Financial Economics, 104(2), 272-287. https://doi.org/10.1016/j.jfineco.2011.11.002

Baker, Malcolm, \& Jeffrey Wurgler. (2006). Investor Sentiment and the Cross-Section of Stock Returns. Journal of Finance, 61, 1645-1680. https://doi.org/10.1111/j.1540-6261.2006.00885.x

Baker, Malcolm, \& Jeffrey Wurgler. (2007). Investor Sentiment in the Stock Market. Journal of Economic Perspectives, 21, 129-151. https://doi.org/10.1257/jep.21.2.129

Barberis, N., Shleifer, A. \& Vishny, R. (1998). A model of investor sentiment. Journal of Financial Economics, 9 , 307-343. https://doi.org/10.1016/S0304-405X(98)00027-0

Bauer, Michael D., \& James D. Hamilton. (2017). Do Macro Variables Help Forecast Interest Rates? FRBSF Economic Letter, 2016-20.

Bergman, N., \& S. Roychowdhury. (2008). Investor sentiment and corporate disclosure. Journal of Accounting Research, 46, 1057-1083. https://doi.org/10.1111/j.1475-679X.2008.00305.x

Black, F. (1986). Noise. The Journal of Finance, 41(3), 529-544. https://doi.org/10.1111/j.1540-6261.1986.tb04513.x

Boudoukh Jacob, Matthew Richardson, \& Robert F. Whitelaw. (2008). The Myth of Long-Horizon Predictability. Review of Financial Studies, 21(4), 1577-1605. https://doi.org/10.1093/rfs/hhl042

Bremmer, Dale. (2008). Consumer Confidence and Stock Prices. $72^{\text {nd }}$ Annual Meeting of the Midwest Economics Association Hyatt Regency, Chicago, Illinois

Brown, G.W. \& Cliff, M.T. (2004). Investor sentiment and the near-term stock market. Journal of Empirical Finance, 11(1), 1-27. https://doi.org/10.1016/j.jempfin.2002.12.001

Brown, G.W. \& Cliff, M.T. (2005). Investor sentiment and asset valuation. Journal of Business, 78(2), 405-440. https://doi.org/10.1086/427633

Campbell, J.Y. \& Kyle, A.S. (1993). Smart money, noise trading and price behavior. The Review of Economic Studies, 60(1), 1-34. https://doi.org/10.2307/2297810

Changsheng $\mathrm{Hu}$, Yongfeng Wang. (2013). Noise trading and stock returns: evidence from China. China Finance Review International, 3(3), 301-315. https://doi.org/10.1108/CFRI-02-2012-0017

Chen, S-S. (2011). Lack of consumer confidence and stock returns. Journal of Empirical Finance, 18(2), 225-236. 
https://doi.org/10.1016/j.jempfin.2010.12.004

Chuang, W-J., Ouyang, L-Y. \& Lo, W-C. (2010). The impact of investor sentiment on excess returns: a Taiwan market cases. International Journal of Information and Management Sciences, 21, 13-28.

Chui, A. C., Titman, S., Wei, K. J. (2010). Individualism and momentum around the world. Journal of Finance, 65(1), 361-392. https://doi.org/10.1111/j.1540-6261.2009.01532.x

Chui, Andy C.W., Sheridan Titman, \& K.C. John Wei. (2008). Individualism and Momentum around the World. AFA 2006 Boston Meetings Paper. https://doi.org/10.2139/ssrn.685767

Daniel, K., Hirshleifer, D., Subrahmanyam, A. (1998). A theory of overconfidence, self-attribution, and security market under- and over-reactions. Journal of Finance, 53. https://doi.org/10.2139/ssrn.2017

De Long, J.B., Shleifer, A., Summers, L.H. \& Waldmann, R.J. (1990). Noise trader risk in financial markets. Journal of Political Economy, 98(4). https://doi.org/10.1086/261703

De Long, J.B., Shleifer, A., Summers, L.H. \& Waldmann, R.J. (1991). The survival of noise traders in financial markets. The Journal of Business, 64(1), 1-19. https://doi.org/10.1086/296523

Fama, E. F. (1970). Efficient capital markets: A review of theory and empirical work. Journal of Finance, 25(2), 383-417. https://doi.org/10.2307/2325486

Fisher, K.L. \& Statman, M. (2003). Consumer confidence and stock returns. Journal of Portfolio Management, 30(1), 115. https://doi.org/10.3905/jpm.2003.319925

Ho, C., Hung, C. H. (2009). Investor sentiment as conditioning information in asset pricing. Journal of Banking \& Finance, 33(5), 892-903. https://doi.org/10.1016/j.jbankfin.2008.10.004

Ho, J.C. \& Hung, C-H. (2012). Predicting stock market returns and volatility with investor sentiment: evidence from eight developed countries. Journal of Accounting and Finance, 12(4), 49-66. https://doi.org/10.2139/ssrn.2279339

Hofstede, G. (2001). Culture's consequences: Comparing values, behaviors, institutions, and organizations across nations (2nd ed.). Beverly Hills, CA: SAGE.

Hsu, C-C., Lin, H-Y. \& Wu, J-Y. (2011). Consumer confidence and stock markets: the panel causality evidence. International Journal of Economics and Finance, 3(6), 91-99. https://doi.org/10.5539/ijef.v3n6p91

Huang, C., Yang, X., Yang, X. \& Sheng, H. (2014). An empirical study of the effect of investor sentiment on returns of different industries. Mathematical Problems in Engineering. https://doi.org/10.1155/2014/545723

Jansen, W.J. \& Nahuis, N.J. (2003). The stock market and consumer confidence: European evidence. Economics Letters, 79(1), 89-98. https://doi.org/10.1016/S0165-1765(02)00292-6

Kahneman, D. \& Tversky, A. (1979). Prospect Theory: An Analysis of Decision under Risk. Econometrica, 47(2), 263-292. https://doi.org/10.2307/1914185

Lee, W.Y., Jiang, C.X. \& Indro, D.C. (2002). Stock market volatility, excess returns, and the role of investor sentiment. Journal of Banking and Finance, 26(12), https://doi.org/10.1016/S0378-4266(01)00202-3

Lemmon, Michael, \& Evgenia Portniaguina. (2006). Consumer Confidence and Asset Prices: Some Empirical Evidence. Review of Financial Studies, 19, 1499-1529. https://doi.org/10.1093/rfs/hhj038

Li, B.H. (2014). Does investor sentiment predict stock returns? The evidence from Chinese stock market. Journal of System Science Complex, 27, 130-143. https://doi.org/10.1007/s11424-013-3291-y

Lux, T. (2011). Sentiment dynamics and stock returns: the case of the German stock market. Empirical Economics, 41, 663-679. https://doi.org/10.1007/s00181-010-0397-0

Naik, Pramod \& Padhi, Puja. (2016). Investor Sentiment, Stock Market Returns and Volatility: Evidence from National Stock Exchange India. International Journal of Management Practice 9(3), 213-237. https://doi.org/10.1504/IJMP.2016.077816

Olsen, R.A. (1998). Behavioral finance and its implications for stock-price volatility. Financial Analysts Journal, 54(2), 10-18. https://doi.org/10.2469/faj.v54.n2.2161

Otoo, M. Ward. (1999). Consumer Sentiment and the Stock Market. Board of Governors of the Federal Reserve System, http://www.federalreserve.gov/pubs/feds/1999/199960/199960pap.pdf 
Perez-Liston, D., Huerta, D. (2012). Does investor sentiment affect Mexican stock market returns and volatility? Global Journal of Finance and Economics, 9(2), 121-132.

Pompian, M. M. (2006). Behavioral Finance and Wealth Management: How to Build Optimal Portfolios That Account for Investor Biases. Hoboken: John Wiley \& Sons.

Schmeling, M. (2009). Investor sentiment and stock returns: some international evidence. Journal of Empirical Finance, 16(3), 394-408. https://doi.org/10.1016/j.jempfin.2009.01.002

Shefrin, H. (2008). Risk and return in behavioral SDF-based asset. Journal of Investment Management, 6(3), 1-18.

Shen, Junyan \& Yu, Jianfeng \& Zhao, Shen. (2017). Investor sentiment and economic forces, Journal of Monetary Economics, 86(C), 1-21. https://doi.org/10.1016/j.jmoneco.2017.01.001

Shiller, Robert J. (2005). Irrational Exuberance, $2^{\text {nd }}$ edition. Princeton, NJ: Princeton University Press.

Shiller, Robert J. (2017). Narrative Economics. American Economic Review, 107(4), 967-1,004. https://doi.org/10.1257/aer.107.4.967

Shleifer and Summers. (1990). The noise trader approach to finance. Journal of Economic perspectives, 419-33. https://doi.org/10.1257/jep.4.2.19

Shleifer A. (2000). Inefficient Markets: An Introduction to Behavioral Finance. Oxford University Press, New York. https://doi.org/10.1093/0198292279.001.0001

Verma, R. \& Soydemir, G. (2009). The impact of individual and institutional investor sentiment on the market price of risk. The Quarterly Review of Economics and Finance, 49, 1129-1145. https://doi.org/10.1016/j.qref.2008.11.001

Verma, R. \& Verma, P. (2007). Noise trading and stock market volatility. Journal of Multinational Financial Management, 17(3), 231-243. https://doi.org/10.1016/j.mulfin.2006.10.003

Wang, Y-H., Keswani, A. \& Taylor, S.J. (2006). The relationships between sentiment, returns and volatility. International Journal of Forecasting, 22, 109-123. https://doi.org/10.1016/j.ijforecast.2005.04.019

Zhu, X. (2012). Investor sentiment and volatility of stock index an empirical analysis from the perspective of behavioral finance. Advances in Applied Economics and Finance, 3(4), 627-629. https://doi.org/10.1111/j.1540-6261.2006.00885.x 